\title{
Effect of collaborative concept mapping teaching strategy on students' achievement in chemistry in selected secondary schools in Kenya
}

\section{Fetnani Cecilia}

\begin{abstract}
In Kenya, the fundamental challenge facing chemistry teaching in secondary schools is how to enhance students' conceptual understanding; a need for meaningful learning. The challenge has led to students' underachievement in chemistry in national examinations. Research findings indicate that teaching method is a crucial factor affecting students' learning and achievement. The present study investigated the effect of Collaborative Concept Mapping (CCM) teaching strategy on students' achievement in Chemistry. Solomon Four Group quasi-experimental research design was used in the study. Four co-educational secondary schools were randomly selected for the study from secondary schools in Bomet District, Kenya. Students in experimental groups were taught using CCM teaching strategy for 8 weeks while the rest were taught using conventional teaching methods. Mole Concept Achievement Test (MCAT) was administered to determine students' achievement on the topic of "mole concept". Results of the study showed that CCM as a teaching strategy had no significant effect on the achievement among students of low and average academic abilities as well as those of higher academic abilities at $0.05 \alpha$ significance level.
\end{abstract}

Key Words: Collaborative Learning, Concept Maps and Achievement

\section{Introduction to the Study}

\section{INTRODUCTION}

The persistently low enrollment in science particularly in secondary schools and tertiary levels of education have aroused concern of science educators, researchers and policy makers the world over (Hardin \& Hilderbrand,1988). As a result most countries are seeking to improve their education standards by promoting programs that not only enhances effective acquisition of rapidly growing bodies of knowledge in a well-organized framework, but also promotes learners' capability to learn meaningfully (Novak, 1998). Even though preponderance of scientific effort swirls around experimental achievements, conceptual achievements continue to be astoundingly important in overall advancement of science (Wagner \& Benavente-McEnery, 2006). 
In Kenya it has been noted that many students shun sciences especially when given an option; this especially applies to girls (Aduda, 2003). Students in Kenya have also been noted to perform poorly generally in sciences (Changeiywo, 2000). Perhaps the poor performance is the one that prompted the Government of Kenya through the Ministry of Education, with assistance of the Government of Japan through Japan International Co-operation Agency (JICA), to initiate a program on Strengthening of Mathematics and Sciences in Secondary School Education (SMASSE). The Government of Kenya recently unveiled its grand plan for changing the country into a newly industrializing, middle-income country providing high quality life for its citizens by the year 2030 (Republic of Kenya, 2007). There is need therefore for Kenya, much more than before to improve on quality of science and technology education to realize the projected goal.

A close analysis of questions performed poorly by candidates in KCSE Chemistry examinations show that students have glaring weaknesses in answering questions. Candidates were noted to have poor interpretation of questions; poor scientific language; poor understanding of concepts and could not relate chemistry knowledge to real life situations (KNEC, 2003, 2005, 2007). According to Staver and Lumpe (1995), students' difficulties in solving problems in chemistry may be traced to several factors, including incomplete understanding of basic concepts, dependence on algorithms, and inability to connect what they know about atoms and molecules to macroscopic levels; problems which are likely derived from poor teaching/learning process.

In the recent past, teaching and learning practices have undergone changes of revolutionary proportions; changes underpinned by shifts in psychological and pedagogical theory in teaching and learning process. The new developments advocates for new approaches to science teaching and learning, not only in schools but also in teacher education ((Lederman, et al., 1994; Roth \& Roychoundry, 1994). Research findings on learning and memory show that for learning to be effective, the learner should be actively involved in the learning process (Shuel, 1993; Matlin, 1994). Piaget believed that there is no true learning unless the students mentally act on information and in the process, assimilate or accommodate what they encounter in their environment (Trowbridge, 2004). Unless this assimilation occurs, teachers and students are involved in pseudo-learning, which is knowledge retained only for short time. 
Meaningful learning occurs when individuals "choose to relate new knowledge to relevant concepts and propositions they already know" (Novak \& Gowin, 1984: 7). Effective strategies designed to promote efficient and meaningful learning rely upon connecting prior knowledge to new concepts (Okebukola \& Jegede, 1988). The importance of meaningful learning in promoting conceptual understanding that in turn facilitates problem solving was stressed by Ausubel (1968); Bransford and Stein (1984) and Eylon and Linn (1988). Research in different areas in chemistry and in other science subjects has established the existence of positive relationships between students' meaningful learning approaches and their achievement in science (BouJaoude, 1992; Cavallo \& Schafer, 1994; Cavallo, 1996; Chan \& Bereiter, 1992; Lee \& Anderson, 1993). According to Ramsden (1983) meaningful learners have a deep approach to learning, that is, they tend to build a holistic description of content, reorganize new content by relating it to prior knowledge and/or to personal experiences, are inclined to use evidence, and maintain a critical and a more objective view. Conversely, rote learners have a surface approach to learning; they have a propensity for memorization of facts and are motivated extrinsically by fear of failure rather than the need to learn and understand (Ramsden, 1983).

One of the innovative cognitive tool which has been advocated as a promoter of meaningful learning in science is the use concept map. Concept map is a schematic device that enables learners to explicitly represent a number of concepts and their interrelationship, that is, it is a diagram showing how concepts within a domain are interrelated (Novak, 1983). Students who use concept mapping techniques are reported to demonstrate superior problem-solving performance (Novak, Gaigne \& Johanassen, 1983). Documented studies also show that there is positive relationship between concept mapping and improvement in science achievement (Heinz entry \& Novak, 1990; Stensvold \& Wilson, 1990; Pankratius, 1990; Horton, McConney, Gallo, Woods, Senn \& Hamelin, 1993). A meta-analysis on studies conducted by Horton et al., (1993) indicated that concept mapping raised student achievement on the average by 0.46 standard deviations, as well as a strong improvement in students' attitude.

In this study concept mapping was taken as a group task where students work collaboratively drawing upon the knowledge of one another to help create their work as they learn chemistry. The social learning theory of Vygotsky states that students work at higher intellectual levels in collaborative or cooperative situations than they can when working individually (Vygotsky, 
1978). In collaborative learning students are responsible for one another's learning as well as their own (Gokhale, 1995). As they make connections between chemistry concepts, other group members will be able to verify whether the interpretations of concept is valid; and they will need to come to consensus on how these concepts are connected. This helps check for misconceptions and help create new understanding of concepts that each member may not have had.

Generally, Learning is considered to be an active, constructive, cumulative, self-regulated and goal-oriented process in which the learner plays a critical role (Trowbridge, 2004). Constructivist theories of learning place the learner in an active role of knowledge construction. Efforts made to translate these new conceptions of learning into classroom practices include development of instructional methods that engage learner actively in the process of knowledge acquisition, this include the use of concept mapping. There is no known study that has been carried out in Kenya to investigate the effect of Collaborative Concept Mapping (CCM) teaching strategy on students' achievement in chemistry with the aim of promoting meaningful learning. The present study was designed in an attempt to fill this gap.

\section{Hypothesis of the Study}

The following null hypothesis was postulated and tested at $0.05 \alpha$ level of significance:

Ho1: There is no significant difference in the achievement between students exposed to Collaborative Concept Mapping (CCM) teaching strategy and those not exposed to it.

\section{METHODOLOGY}

\section{Research Design}

The study adopted a Solomon Four Group quasi-experimental research design. The research design is represented as follows:-

Group $1\left(\mathrm{E}_{1}\right) \quad \mathrm{O}_{1} \quad \mathrm{X} \quad \mathrm{O}_{2}$

Group $2\left(\mathrm{C}_{1}\right) \mathrm{O}_{3} \_\mathrm{O}_{4}$ 


\section{Group $3\left(\mathrm{E}_{2}\right)-\mathrm{X} \mathrm{O}_{5}$}

$$
\text { Group } 4\left(\mathrm{C}_{2}\right) \quad \ldots \quad-\mathrm{O}_{6}
$$

Where: $\quad \mathrm{O}_{1}$ and $\mathrm{O}_{3}$ are pre-tests

$\mathrm{O}_{2} ; \mathrm{O}_{4}, \mathrm{O}_{5}, \& \mathrm{O}_{6}$ are post-test

$\mathrm{X}$ is the treatment where students will be taught by use of CCM

-------- indicates non-equivalent groups

Group 1 is the experimental group which received the pretest $\left(\mathrm{O}_{1}\right)$, the treatment $(\mathrm{X})$ and the post-test $\left(\mathrm{O}_{2}\right)$. Group 2 is the true control group which received a pre-tests $\left(\mathrm{O}_{3}\right)$ followed by the control condition and finally a post-test $\left(\mathrm{O}_{4}\right)$. Group 3 received the treatment $(\mathrm{X})$ and post-test $\left(\mathrm{O}_{5}\right)$ only, but did not receive pretest while Group IV received post-tests $\left(\mathrm{O}_{6}\right)$ only. Groups 2 and 4 were taught through the conventional teaching methods.

\section{Participants}

The target population of the study was Form Three chemistry students in secondary schools in Kenya. The accessible population however was the 4,231 chemistry students in co-educational secondary schools in Bomet District. The sampling units in this study were secondary schools and not the individual students. Based on the research design adopted, four (4) Co-educational secondary schools were selected for the study using cluster sampling technique. Preliminary assessment of all the schools was done before selection; this was done to ensure that all the schools forming the sampling frame were suitable for the study. Preliminary information sought included experience and qualification of chemistry teachers as well as extent of syllabus coverage in form three chemistry classes. The 4 schools selected were randomly assigned into treatment and control conditions to form 4 groups. A total of 166 students participated in the study. 


\section{Research Instrument}

Mole Concept Achievement Test (MCAT) was administered to the students to determine the students' achievement level 1(MCA1) on the topic "mole concept". To enhance reliability and validity, the instrument was piloted in schools from the neighboring Narok District. The test was also given to two expert in science education and two experienced chemistry teachers to assess the content as well as the appropriateness of the test to Form Three chemistry students.

\section{Data Collection Procedures}

Chemistry teachers from participating schools were trained by the researcher on construction of concept maps as well as the expectations and procedures on CCM teaching strategy. Ethical issues in the study were also addressed during the training of these teachers. This was done to ensure that all the teachers involved in the research adhered to the standard conduct of research. To ensure that there was as much uniformity in the presentation of content on the chosen topic; the researcher met with all the four teachers involved in the study on weekly basis. In these meetings discussions on the content, problems as well instructional approaches applied was done. Emphasis on certain aspects of teaching was also addressed in these meetings; this was particularly important to ensure that teachers in experimental group adhered to all the set instructional conditions of the treatment. Teachers in the experimental group were also issued with instructional manuals specifically designed for the topic of "mole concept" to enhance their adherence to treatment conditions. All the teachers involved in the study adopted a common schemes of work developed jointly with the researcher for the topic of mole concept; this ensured that the intended content was covered uniformly for all the groups involved in the study.

Before the treatment started, students in experimental groups were trained by the respective teachers on concept mapping skills for a period of two weeks. After this period pretest was administered to group 1 and group 2. The treatment was then administered for a period of 8 weeks. The control groups were taught using regular teaching methods. Soon after the treatment period, a posttest was administered. The research instruments were administered by the researcher with help of subject teachers in both the pretest and posttest. 


\section{RESULTS AND DISCUSSION}

\section{Effect of Collaborative Concept Mapping on Students' Achievement}

The students in groups 1 and 2 were pretested on Mole Concept Achievement level 1 (MCA1) using MCAT. Here students work was scored for right or wrong answer(s) without analyzing the reasoning and skills applied in answering the questions. The Sum, Mean, Standard Deviation (SD), Kurtosis and Skewness on pretest results are presented in Table 1.

Table 1: Summary on Students' Pre-test Scores in MCA1

\begin{tabular}{llllll}
\hline Group & Sum & Mean & SD & KURTOSIS & SKEWNESS \\
\hline 1 (Experimental 1) & 40.000 & .86957 & .777709 & -1.289 & .235 \\
$2($ Control 1) & 33.000 & .80488 & .714826 & -.947 & .307 \\
\hline Total & $\mathbf{7 3 . 0 0 0}$ & $\mathbf{. 8 3 9 0 8}$ & $\mathbf{. 7 4 5 1 1 7}$ & $\mathbf{- 1 . 1 4 2}$ & $\mathbf{. 2 7 1}$ \\
\hline
\end{tabular}

The results in Table 1 showed that distribution of scores obtained from MCA1 was almost normally distributed in both experimental and control group despite the slight Kurtosis to the left and slight Skewness to the right compared to standard normal distribution. The mean values for pretest scores was 0.86957 and 0.80488 for experimental and control group respectively out of a maximum score of 10 points. To test whether there was any significant difference in means, independent t-Test was performed and the results are presented in Table 2.

Table 2: Independent Samples t-Test on pretest Scores in MCA1 


\begin{tabular}{lllllllll}
\hline & & & $\begin{array}{c}\text { Levene's Test } \\
\text { for Equality of } \\
\text { Variances }\end{array}$ & & & & \\
& & & & & & & \\
& & F & Sig. & T & Df & $\begin{array}{c}\text { Sig. (2- } \\
\text { tailed) }\end{array}$ & $\begin{array}{c}\text { Mean } \\
\text { Difference }\end{array}$ \\
$\begin{array}{l}\text { Pretest scores } \\
\text { on MCAT1 }\end{array}$ & $\begin{array}{l}\text { Equal variances } \\
\text { assumed }\end{array}$ & .369 & .545 & .402 & 85 & .689 & .064687 \\
& $\begin{array}{l}\text { Equal variances } \\
\text { not assumed }\end{array}$ & & & & .404 & 84.912 & .687 & .064687 \\
\end{tabular}

The results in Table 8 showed no significant difference in the two means $\left(\mathrm{t}_{(85)}=.689, \mathrm{p}>0.05\right)$ which implied that the level of achievement abilities prior to administration of the intervention for the two groups were similar; that is the groups were equivalent before treatment. The means on post-test scores on MCA1 for all the 4 groups are presented in Table 3.

Table 3: Mean Scores on Post Test MCAT1

\begin{tabular}{lccc}
\hline Group & $\mathbf{N}$ & Mean & Std. Deviation \\
\hline 1 (Experimental 1) & 41 & 7.92683 & 6.860722 \\
2 Control 1 & 41 & 5.85366 & 4.390677 \\
$3($ Experimental 2) & 43 & 9.81395 & 6.087676 \\
$4($ Control 2) & 41 & 8.12195 & 8.732683 \\
Total & 166 & 7.95181 & 6.783051 \\
\hline
\end{tabular}

From Table 9 the highest mean score was attained by group 3 (Experimental 2) followed by group 4 (control 2) then group 1 (Experimental 1) and finally group 2 (Control 1). To test for mean differences in posttest MCA1, ANCOVA was run with Kenya Certificate of Primary Education (KCPE) marks as covariate. This analysis was necessary to control any pre-existing potential differences in students' academic abilities. Since ANCOVA is a blend of ANOVA and regression, it was deemed necessary to determine suitability of KCPE as a covariate by running homogeneity of regression. The result of this test is depicted in Table 4.

Table 4: Test on Homogeneity of Regression on KCPE 


\begin{tabular}{lccccc}
\hline Source & $\begin{array}{c}\text { Type III Sum } \\
\text { of Squares }\end{array}$ & Df & $\begin{array}{c}\text { Mean } \\
\text { Square }\end{array}$ & F & Sig. \\
\hline $\begin{array}{l}\text { Corrected } \\
\text { Model }\end{array}$ & $2141.350(\mathrm{a})$ & 7 & 305.907 & 8.868 & .000 \\
Intercept & 203.029 & 1 & 203.029 & 5.886 & .016 \\
GROUP & 966.888 & 3 & 322.296 & 9.343 & .000 \\
KCPE & 595.236 & 1 & 595.236 & 17.256 & .000 \\
GROUP $*$ & 1011.231 & 3 & 337.077 & 9.772 & .000 \\
KCPE & 5450.265 & 158 & 34.495 & & \\
Error & 18088.000 & 166 & & & \\
Total & 7591.614 & 165 & & & \\
Corrected & & & & \\
Total & & & & \\
\hline
\end{tabular}

\section{$R$ Squared $=.282($ Adjusted $R$ Squared $=.250)$}

The results in Table 4 showed that the interaction term (GROUP*KCPE) was significant $\left(\mathrm{F}_{(3,158)}\right.$ $=9.772, \mathrm{p}<0.05)$. This meant that the assumption on homogeneity of regression, a requirement for this type of test, was not tenable. Levene's test on homogeneity variance however, showed no significant difference in variance in the groups as depicted in Table 5.

Table 5: Levene's Test of Equality of Error Variances

\begin{tabular}{cccc}
$F$ & df1 & df2 & Sig. \\
1.558 & 3 & 162 & .202 \\
\hline
\end{tabular}

Design: Intercept $+G R O U P+K C P E+G R O U P * K C P E$

KCPE means for the four groups of students were as presented in Table 6. The means are 313.36585, 298.56098, 317.06977 and 297.63415 respectively for groups 1, 2, 3 and 4.

Table 6: KCPE Mean Marks 


\begin{tabular}{llrr}
\hline Group & Mean & N & Std. Deviation \\
\hline 1 & 313.36585 & 41 & 26.214267 \\
2 & 298.56098 & 41 & 26.362899 \\
3 & 317.06977 & 43 & 34.318810 \\
4 & 297.63415 & 41 & 32.280610 \\
\hline Total & 306.78313 & 166 & 31.039193 \\
\hline
\end{tabular}

Violation on assumption on homogeneity of regression necessitated splitting of students in each of the 4 groups into two sub-groups based on KCPE achievement. The sub-groups were re-coded KCPE LOW and KCPE HIGH. Students who had KCPE marks in the range of 200-320 formed the first sub-group of KCPE LOW while those who had marks in the range of 321-399 formed the second sub-group of KCPE HIGH (no student scored marks less than 200 and none scored marks above 399). Distribution of students in each sub-group was as presented in Table 7.

Table 7: Categorization of Students to Sub-groups

\begin{tabular}{lllll}
\hline Sub-group & $\begin{array}{c}\text { Experimental 1 } \\
\text { (Group 1) }\end{array}$ & $\begin{array}{l}\text { Control 1 } \\
\text { (Group 2) }\end{array}$ & $\begin{array}{c}\text { Experimental 2 } \\
\text { (Group 3) }\end{array}$ & $\begin{array}{l}\text { Control 2 } \\
\text { (Group 4) }\end{array}$ \\
\hline KCPE LOW (200-320 Marks) & 24 & 32 & 23 & 32 \\
KCPE HIGH (321-399 Marks) & 17 & 9 & 20 & 9 \\
\hline Total & $\mathbf{4 1}$ & $\mathbf{4 1}$ & $\mathbf{4 3}$ & $\mathbf{4 1}$ \\
\hline
\end{tabular}

Analysis on the KCPE means on the two sub-groups was then carried out. The KCPE mean marks of the first sub-group (KCPE LOW) were as shown in Table 8.

Table 8: KCPE Mean Marks for KCPE LOW Sub-group 


\begin{tabular}{cccc}
\hline Sub-group & N & KCPE Mean & Std. Deviation \\
\hline 1.00 & 24 & 296.62500 & 17.586587 \\
2.00 & 32 & 287.68750 & 17.122778 \\
3.00 & 23 & 292.47826 & 25.482382 \\
4.00 & 32 & 284.09375 & 15.276715 \\
\hline
\end{tabular}

Table 9 presents the KCPE mean marks of the second sub-group (KCPE HIGH). The means are $337.000,337.222,345.350$ and 345.777 respectively for group 1, 2, 3 and 4 .

Table 9: KCPE Mean Marks for KCPE HIGH Sub-Group

\begin{tabular}{cccc}
\hline Group & N & Mean & Std. Deviation \\
\hline 1.00 & 17 & 337.00000 & 16.109004 \\
2.00 & 9 & 337.22222 & 13.581033 \\
3.00 & 20 & 345.35000 & 16.664728 \\
4.00 & 9 & 345.77778 & 31.063555 \\
Total & 55 & 341.50909 & 19.048547 \\
\hline
\end{tabular}

Test results on the use of KCPE as covariate in the first sub-group (KCPE LOW) showed that the assumption on the homogeneity of regression was tenable; the interaction term, $\mathrm{KCPE}$ LOW*KCPE, was insignificant $\left(\mathrm{F}_{(3,103)}=0.406, \mathrm{p}>0.05\right)$ as depicted by the results in Table 10 .

Table 10: KCPE Test on Homogeneity of Variance for KCPE LOW 


\begin{tabular}{lccccc}
\hline Source & $\begin{array}{c}\text { Type III Sum } \\
\text { of Squares }\end{array}$ & df & $\begin{array}{c}\text { Mean } \\
\text { Square }\end{array}$ & F & Sig. \\
\hline Corrected Model & $468.471(\mathrm{a})$ & 7 & 66.924 & 2.482 & .021 \\
Intercept & 34.398 & 1 & 34.398 & 1.276 & .261 \\
KCPELOW & 81.738 & 3 & 27.246 & 1.011 & .391 \\
KCPE & 108.733 & 1 & 108.733 & 4.033 & .047 \\
KCPELOW * & 79.181 & 3 & 26.394 & .979 & .406 \\
KCPE & 2777.114 & 103 & 26.962 & & \\
Error & 8219.000 & 111 & & & \\
Total & 3245.586 & 110 & & & \\
Corrected Total & & & &
\end{tabular}

$R$ Squared $=.144$ (Adjusted $R$ Squared $=.086)$

Test results on homogeneity of regression on the use of KCPE as covariate in the second subgroup also showed that there was no significance in the interaction term, KCPE HIGH*KCPE, F $(3,47)=2.272, \mathrm{p}>0.05$ as depicted by the results in Table 11 .

Table 11: KCPE Test on Homogeneity of Variance for KCPE HIGH

\begin{tabular}{cccccc}
\hline Source & $\begin{array}{c}\text { Type III Sum of } \\
\text { Squares }\end{array}$ & df & $\begin{array}{c}\text { Mean } \\
\text { Square }\end{array}$ & F & Sig. \\
\hline Corrected Model & $1265.552(\mathrm{a})$ & 7 & 180.793 & 3.332 & .006 \\
Intercept & 20.940 & 1 & 20.940 & .386 & .537 \\
KCPEHIGH & 311.869 & 3 & 103.956 & 1.916 & .140 \\
KCPE & 66.125 & 1 & 66.125 & 1.219 & .275 \\
KCPEHIGH $*$ & 369.838 & 3 & 123.279 & 2.272 & .092 \\
KCPE & 2550.193 & 47 & 54.259 & & \\
Error & 9869.000 & 55 & & & \\
Total & 3815.745 & 54 & & & \\
Corrected Total & & & & & \\
\hline
\end{tabular}


$R$ Squared $=.332($ Adjusted $R$ Squared $=.232)$

Test results on assumptions on homogeneity of variance in both sub-groups were also found tenable. Tests results for these analyses are presented in Table $12\left(\mathrm{~F}_{(3,107)}=0.142, \mathrm{p}>0.05\right)$ and Table $13\left(\mathrm{~F}_{(3,51)}=0.465, \mathrm{p}>0.05\right)$ for KCPE LOW and KCPE HIGH sub-groups respectively.

Table 12: Levene's Test of Equality of Error Variances(a)

\begin{tabular}{cccc}
\hline $\mathrm{F}$ & $\mathrm{df} 1$ & $\mathrm{df} 2$ & Sig. \\
\hline 1.853 & 3 & 107 & .142 \\
\hline
\end{tabular}

Design: Intercept+KCPELOW+KCPE+KCPELOW*KCPE

Table 13: Levene's Test of Equality of Error Variances(a)

\begin{tabular}{cccc}
\hline $\mathrm{F}$ & $\mathrm{df} 1$ & $\mathrm{df} 2$ & Sig. \\
\hline .865 & 3 & 51 & .465 \\
\hline
\end{tabular}

Design: Intercept $+K C P E H I G H+K C P E+K C P E H I G H * K C P E$

ANCOVA analyses on students' achievement on MCA1 resulted on adjusted means. The actual as well as the adjusted means for KCPE LOW sub-group are presented in Table 14.

Table 14: Means on MCA1 for KCPE LOW

\begin{tabular}{lccc}
\hline KCPE 200-320 & N & Actual Mean & Adjusted Mean \\
\hline EXPERIMENTAL 1 (group1) & 24 & 7.66667 & $7.290(\mathrm{a})$ \\
CONTROL 1 (group 2) & 32 & 5.53125 & $5.632(\mathrm{a})$ \\
EXPERIMENTA 2 (group 3) & 23 & 9.26087 & $9.106(\mathrm{a})$ \\
CONTROL 2 (group 4) & 32 & 5.28125 & $5.574(\mathrm{a})$ \\
\hline
\end{tabular}

Covariates appearing in the model are evaluated at the following values: KCPE marks = 289.57658 .

ANCOVA Analysis on the adjusted means for KCPE LOW sub-group showed that there were no significant differences in the achievement of students in MCA1 $\left(\mathrm{F}_{(3,106)}=2.619, \mathrm{p}>0.05\right)($ Table 15). It is worth noting however, that the posttest scores of experimental groups (groups 1 and 3) 
were higher than those of the control groups (groups 2 and 4) before and even after adjustment on covariate. This suggests that even though the MCAT1 mean difference was not significant at $\alpha=$ 0.05 significance level; the CCM intervention may have contributed to the better achievement in the experimental groups.

Table 15: ANCOVA Results on MCAT1 for KCPE LOW

\begin{tabular}{lccccc}
\hline Source & $\begin{array}{c}\text { Type III Sum of } \\
\text { Squares }\end{array}$ & Df & $\begin{array}{c}\text { Mean } \\
\text { Square }\end{array}$ & F & Sig. \\
\hline Corrected Model & $389.291(\mathrm{a})$ & 4 & 97.323 & 3.612 & .008 \\
Intercept & 32.891 & 1 & 32.891 & 1.221 & .272 \\
KCPE & 107.911 & 1 & 107.911 & 4.005 & .048 \\
KCPE LOW & 211.676 & 3 & 70.559 & 2.619 & .055 \\
Error & 2856.295 & 106 & 26.946 & & \\
Total & 8219.000 & 111 & & & \\
Corrected Total & 3245.586 & 110 & & & \\
\hline
\end{tabular}

$R$ Squared $=.120($ Adjusted $R$ Squared $=.087)$

Table 16 presents actual as well as adjusted means on MCA1 for the KCPE HIGH sub-group.

Table 16: Means on MCA1 for KCPE HIGH

\begin{tabular}{lccc}
\hline KCPE 321-399 & N & Actual Mean & Adjusted Mean \\
\hline EXPERIMENTAL 1 (group1) & 24 & 8.29412 & $8.720(\mathrm{a})$ \\
CONTROL 1 (group 2) & 32 & 7.00000 & $7.405(\mathrm{a})$ \\
EXPERIMENTA 2 (group 3) & 23 & 10.45000 & $10.087(\mathrm{a})$ \\
CONTROL 2 (group 4) & 32 & 18.22222 & $17.819(\mathrm{a})$ \\
\hline
\end{tabular}

Covariates appearing in the model are evaluated at the following values: KCPE marks = 341.50909 . 
ANCOVA on the MCA1 adjusted means for KCPE HIGH subgroup showed significant differences in achievements of groups $\left(\mathrm{F}_{(3,50)}=3.497, \mathrm{p}<0.05\right)$ as shown by results in Table 17.

Table 17: ANCOVA Results on MCA1 for KCPE LOW

\begin{tabular}{lccccc}
\hline Source & Type III Sum of Squares & df & Mean Square & F & Sig. \\
\hline $\begin{array}{l}\text { Corrected } \\
\text { Model }\end{array}$ & $895.714(\mathrm{a})$ & 4 & 223.929 & 3.834 & .009 \\
Intercept & 71.838 & 1 & 71.838 & 1.230 & .273 \\
KCPE & 166.004 & 1 & 166.004 & 2.843 & .098 \\
KCPE HIGH & 612.602 & 3 & 204.201 & 3.497 & .022 \\
Error & 2920.031 & 50 & 58.401 & & \\
Total & 9869.000 & 55 & & & \\
Corrected Total & 3815.745 & 54 & & & \\
\end{tabular}

$R$ Squared $=.235($ Adjusted $R$ Squared $=.174)$

A Bonferroni post-hoc analysis was carried out to find out where the differences actually existed. Bonferroni analysis was preferred for this study because it controls for the overall error rate hence the observed significance level is adjusted for the fact that multiple comparisons are being made. The results of this analysis were as shown in Table 18. 
Table 18: Bonferroni post-hoc analysis on MCA1 for KCPE LOW

\begin{tabular}{ccccc}
\hline \multirow{2}{*}{ (I) KCPE 321-399 } & (J) KCPE 321-399 & $\begin{array}{c}\text { Mean } \\
\text { Difference }(\mathbf{I}-\mathbf{J})\end{array}$ & $\begin{array}{c}\text { Std. } \\
\text { Error }\end{array}$ & Sig.(a) \\
\hline 1.00 & 2.00 & 1.315 & 3.150 & 1.000 \\
& 3.00 & -1.368 & 2.564 & 1.000 \\
& 4.00 & $-9.099\left(^{*}\right)$ & 3.188 & .038 \\
2.00 & 1.00 & -1.315 & 3.150 & 1.000 \\
& 3.00 & -2.683 & 3.101 & 1.000 \\
& 4.00 & $-10.414\left(^{*}\right)$ & 3.634 & .036 \\
3.00 & 1.00 & 1.368 & 2.564 & 1.000 \\
& 2.00 & 2.683 & 3.101 & 1.000 \\
& 4.00 & -7.732 & 3.068 & .090 \\
4.00 & 1.00 & $9.099\left(^{*}\right)$ & 3.188 & .038 \\
& 2.00 & $10.414\left(^{*}\right)$ & 3.634 & .036 \\
& 3.00 & 7.732 & 3.068 & .090 \\
\hline
\end{tabular}

* The mean difference is significant at the .05 level.

Adjustment for multiple comparisons: Bonferroni.

The results in Table 18 showed that the mean difference between group 1 and group 4 and that between group 2 and group 4 were significant in favour of group 4 . The mean difference between group 3 and group 4 were however insignificant. This suggests that CCM teaching strategy as an intervention had no significant effect on students' achievement in the KCPE HIGH sub-group.

\section{Discussions of Results}

The results of the study indicated no significant differences in the achievement of students in experimental and control groups in both the KCPE LOW and KCPE HIGH subgroups. Despite the insignificant mean difference in MCA1, it was noted however that the means of experimental groups (groups 1 and 3) in KCPE LOW sub-group were higher compared to that of control 
groups (groups 2 and 4) before and after adjustment on covariate. The enhanced achievement among students in the KCPE LOW sub-group was probably due to the effects of CCM intervention. There was no evidence however that CCM intervention had any beneficial effect on MCA1 among the students in the KCPE HIGH subgroup. This suggests that CCM probably has more beneficial effects on achievement of students of low and average academic abilities.

The findings of this study are consistent with the findings of BouJaoude and Attieh (2008) on the effect of using Concept Maps as study tools on achievement in chemistry in co-educational schools in Lebanon. Results from BouJaoude and Attieh study showed that the mean score on chemistry achievement post-test for the experimental group exceeded that of the control group but the difference was not statistically significant. The study also dealt with differential effect of using concept maps on high and low achieving students as was done in the present study. Unlike the present study however, chemistry achievement was scored at different levels based on Bloom's taxonomy before the overall achievement was considered. The means of achievement of level group I (students who scored below the mean) in the experimental group were higher than those in the control group for the comprehension level questions, the application-and-above level questions, and for the total scores. The results showed that concept mapping helped students who scored below test scores mean (achievement level group I) achieve better on high cognitive level questions. The finding suggested that concept maps was more beneficial to students who scored below average; a finding which corroborates the finding of the present study.

The findings of this study also parallel results obtained by Stensvold and Wilson (1992) on the effect of students' construction of concept map in high school chemistry laboratories on comprehension of chemical concepts. Among students with high abilities, those who constructed concept maps scored lower on comprehension test than those who did not construct maps. However, among students with lower abilities, those who constructed concept maps scored higher than those who did not. Stensvold and Wilson suggested that concept maps may disadvantage high ability students who may be having their own successful strategies which they fail to apply when they use concept maps. Evidence from other researches suggests that concept mapping as a strategy promote meaningful learning; and is particularly useful for students who have traditionally experienced difficulty when learning science (Lehman, Carter \& Kahle, 1985; 
Okebukola \& Jegede, 1988; Stensvold \& Wilson, 1990). It is also claimed to be more beneficial to students who are at risk of failing in school (Anderson-Inman, Knox-Quinn \& Horney, 1996).

Based on the findings of this study and corroborated by research findings discussed; CCM as a teaching strategy is more beneficial to students of low and average academic abilities. This is

probably because high achievers might be having their own successful strategies, which they may fail to employ when they use concept maps and thus get disadvantaged in the process. Studies have shown that concept map construction is a difficult process (Lehman et al, 1985); thus students need a lot of training to master the technique if they are to derive any benefits from it (Beyerebach \& Smith, 1990; Brandt et al., 2001). It is possible that conformity of students with low and average academic abilities to teachers' demand as well as their consistency in the use of concept maps; enabled them master the technique as opposed to high achievers who are probably predisposed to employ alternative learning strategies. The situation, however, does not suggest that concept mapping is a solution for all problems in learning chemistry because, as Zoller (1990) pointed out, there are chemistry concepts that are abstract, non-intuitive, and not directly interrelated and cannot be taught by using concept mapping.

\section{Implications}

Anecdotal evidence shows that students with low and average academic abilities struggle to learn chemistry, but are often unsuccessful because most of them perceive concepts in chemistry as disjointed. This is probably because many of them do not construct appropriate understandings of fundamental chemical concepts throughout their educational experiences (Nakhleh, 1992). Instead of having well-structured and integrated domain-specific knowledge structures, students consider chemical concepts as isolated elements of knowledge. The lack of integration may be the main reason for difficulties in concept formation and application of acquired knowledge (Brandt et al., 2001); which probably leads to underachievement in chemistry among this group of learners. The finding in this study corroborated by similar research done elsewhere suggests that CCM as a teaching/learning strategy enhance achievement of students of low and average academic abilities. Thus CCM teaching strategy can be use to address the perennial problem of underachievement in chemistry examinations especially among students with low and average academic abilities. There is need however to scrutinize the learning strategies employed by 
students with higher academic abilities in order to identify ways in which the benefits of CCM strategy can be harnessed to benefit them too.

\section{REFERENCES}

Setiawan, Adib Rifqi. (2017, February 24). Penerapan Pendekatan Saintifik untuk Melatihkan Literasi Saintifik dalam Domain Kompetensi pada Topik Gerak Lurus di Sekolah Menengah Pertama. Undergraduate Thesis. Bandung: Universitas Pendidikan Indonesia. URL: http://repository.upi.edu/29074/

Setiawan, Adib Rifqi. (2020, April 21). Lembar Kegiatan Literasi Saintifik untuk Pembelajaran Jarak Jauh Topik Penyakit Coronavirus 2019 (COVID-19). Edukatif: Jurnal Ilmu Pendidikan, 02(01): 28-37. DOI: https://doi.org/10.31004/edukatif.v2i1.80

Setiawan, Adib Rifqi. (2020, March 01). Pendidikan Literasi Finansial Melalui Pembelajaran Fiqh Mu'āmalāt Berbasis Kitab Kuning. Nazhruna: Jurnal Pendidikan Islam, 03(01): 138-159. DOI: https://dx.doi.org/10.31538/nzh.v3i1.522

Setiawan, Adib Rifqi. (2020, January 24). Pembelajaran Tematik Berorientasi Literasi Saintifik. Jurnal Basicedu: Journal of Elementary Education, 04(01): 71-80. URL: https://jbasic.org/index.php/basicedu/article/view/298

Setiawan, Adib Rifqi. (2019, December 30). Instrumen Penilaian Pembelajaran Fiqh Mu'āmalāt Berorientasi Literasi Finansial. Eklektik: Jurnal Pendidikan Ekonomi dan Kewirausahaan, 02(02): 258-272. DOI: http://dx.doi.org/10.24014/ekl.v2i2.8117

Setiawan, Adib Rifqi. (2019, December 20). Literasi Saintifik Berdasarkan Kecerdasan Majemuk dan Motivasi Belajar. Media Penelitian Pendidikan: Jurnal Penelitian dalam Bidang Pendidikan dan Pengajaran, 13(02): 126-137. DOI: http://dx.doi.org/10.26877/mpp.v13i2.4913

Setiawan, Adib Rifqi; Puspaningrum, Mita; \& Umam, Khoirul. (2019, December 06). Pembelajaran Fiqh Mu'āmalāt Berorientasi Literasi Finansial. Tarbawy: Indonesian Journal of Islamic Education, 06(02): 187-102. URL: https://ejournal.upi.edu/index.php/tarbawy/article/view/20887

Setiawan, Adib Rifqi. (2019, October 02). Efektivitas Pembelajaran Biologi Berorientasi Literasi Saintifik. Thabiea : Journal of Natural Science Teaching, 02 (02): 83-94. DOI: http://dx.doi.org/10.21043/thabiea.v2i2.5345

Setiawan, Adib Rifqi. (2019, September 30). Instrumen Penilaian untuk Pembelajaran Ekologi Berorientasi Literasi Saintifik. Assimilation: Indonesian Journal of Biology Education, 02(02): 42-46. DOI: https://dx.doi.org/10.17509/aijbe.v2i2.19250

Setiawan, Adib Rifqi; Mufassaroh, Arij Zulfi. (2019, June 28). Menyusun Soal Literasi Saintifik untuk Pembelajaran Biologi Topik Plantae dan Animalia. BIOSFER: Jurnal Biologi dan Pendidikan Biologi, 04(01): 33-40. URL: http://dx.doi.org/10.23969/biosfer.v4i1.1484

Setiawan, Adib Rifqi. (2019, June 26). Peningkatan Literasi Saintifik melalui Pembelajaran Biologi Menggunakan Pendekatan Saintifik. Journal of Biology Education, 02(01): 223-235. URL: http://journal.stainkudus.ac.id/index.php/jbe/article/view/5278

Setiawan, Adib Rifqi; Utari, Setiya; Nugraha, Muhamad Gina. (2017, September 22). Mengonstruksi Rancangan Soal Domain Kompetensi Literasi Saintifik Siswa SMP Kelas VIII pada Topik 
Gerak Lurus. Wahana Pendidikan Fisika, 02(02): 44-48. URL:

https://ejournal.upi.edu/index.php/WPF/article/view/8277/0

Setiawan, Adib Rifqi. (2020, April 20). Menyusun Instrumen Penilaian untuk Pembelajaran Ekologi Berorientasi Literasi Saintifik. Prosiding Seminar Nasional dan Workshop Biologi-IPA dan Pembelajaran Ke-4 (SnoWBel IV): 241-9. ISBN : 978-602-470-170-3 \& e-ISBN : 978-602-470-171-0.

Setiawan, Adib Rifqi. (2020, February 18). Menyusun Instrumen Penilaian untuk Pembelajaran Topik Lingkungan Berorientasi Literasi Saintifik. Prosiding Seminar Nasional Fisika (SiNaFi) 2019: 15-21. URL: http://proceedings.upi.edu/index.php/sinafi/article/view/563

Setiawan, Adib Rifqi. (2020, January 17). Penggunaan Mabadi 'Asyroh dalam Pembelajaran Biologi untuk Meningkatkan Motivasi dan Hasil Belajar. Prosiding Seminar Nasional Biologi 2019 Inovasi Penelitian dan Pembelajaran Biologi III (IP2B III): 158-164. URL: http://semnasbiologi.conference.unesa.ac.id/ocs/index.php/semnasbio/IP2BIII/paper/view File/11/21

Setiawan, Adib Rifqi. (2020, January 17). Upaya Meningkatkan Motivasi Belajar dalam Pembelajaran Ilmu Pengetahuan Alam (IPA) Melalui Bacaan Populer. Prosiding Seminar Nasional Biologi 2019 Inovasi Penelitian dan Pembelajaran Biologi III (IP2B III): 154-157. URL: http://semnasbiologi.conference.unesa.ac.id/ocs/index.php/semnasbio/IP2BIII/paper/view File/5/51

Setiawan, Adib Rifqi. (2020, January 17). Penerapan Pendekatan Saintifik dalam Pembelajaran Biologi sebagai Upaya Melatih Literasi Saintifik. Prosiding Seminar Nasional Biologi 2019 Inovasi Penelitian dan Pembelajaran Biologi III (IP2B III): 140-145. URL: http://semnasbiologi.conference.unesa.ac.id/ocs/index.php/semnasbio/IP2BIII/paper/view File/6/19

Setiawan, Adib Rifqi. (2019, October 14). Penyusunan Program Pembelajaran Biologi Berorientasi Literasi Saintifik. Seminar Nasional Sains \& Entrepreneurship VI (SNSE VI): 255-1-8. URL: http://conference.upgris.ac.id/index.php/snse/article/view/255

Setiawan, Adib Rifqi. (2019, May 07). Penerapan Pendekatan Saintifik untuk Melatih Literasi Saintifik dalam Domain Kompetensi pada Topik Gerak Lurus di Sekolah Menengah Pertama. Prosiding Seminar Nasional Fisika (SiNaFi) 2018: 7-13. URL: http://proceedings.upi.edu/index.php/sinafi/article/view/355

Setiawan, Adib Rifqi. (2019, November 23). Profil Literasi Saintifik Berdasarkan Kecerdasan Majemuk dan Motivasi Belajar. Seminar Nasional Fisika V (SiNaFi 5.0), Universitas Pendidikan Indonesia (UPI). DOI: https://dx.doi.org/10.35542/osf.io/m7n95

Setiawan, Adib Rifqi. (2019, November 23). Menyusun Instrumen Penilaian untuk Pembelajaran Topik Lingkungan Berorientasi Literasi Saintifik. Seminar Nasional Fisika V (SiNaFi 5.0), Universitas Pendidikan Indonesia (UPI). DOI: https://dx.doi.org/10.35542/osf.io/sc6d2

Setiawan, Adib Rifqi. (2019, November 23). Analisis Keabsahan dan Keandalan Science Motivation Questionnaire II (SMQ II) Versi Bahasa Indonesia. Seminar Nasional Fisika V (SiNaFi 5.0), Universitas Pendidikan Indonesia (UPI). DOI: https://doi.org/10.31237/osf.io/6zeph

Setiawan, Adib Rifqi. (2019, October 05). Menyusun Instrumen Penilaian untuk Pembelajaran Ekologi Berorientasi Literasi Saintifik. Seminar Nasional \& Workshop Biologi, IPA, dan Pembelajarannya ke-4 (SnoWBel IV), Universitas Negeri Malang (UM). DOI: https://dx.doi.org/10.13140/RG.2.2.21931.39206 
Setiawan, Adib Rifqi. (2019, August 21). Penyusunan Program Pembelajaran Biologi Berorientasi Literasi Saintifik. Seminar Nasional Sains \& Entrepreneurship VI (SNSE VI), Universitas PGRI Semarang (UPGRIS). DOI: https://dx.doi.org/10.13140/RG.2.2.13716.86400

Setiawan, Adib Rifqi. (2019, March 23). Upaya Meningkatkan Motivasi Belajar dalam Pembelajaran Ilmu Pengetahuan Alam (IPA) Melalui Bacaan Populer. Seminar Nasional Biologi 2019 Inovasi Penelitian dan Pembelajaran Biologi III (IP2B III), Universitas Negeri Surabaya (UNESA). DOI: https://dx.doi.org/10.13140/RG.2.2.13087.71847

Setiawan, Adib Rifqi. (2019, March 23). Penerapan Pendekatan Saintifik dalam Pembelajaran Biologi sebagai Upaya Melatih Literasi Saintifik Siswa Sekolah Menengah. Seminar Nasional Biologi 2019 Inovasi Penelitian dan Pembelajaran Biologi III (IP2B III), Universitas Negeri Surabaya (UNESA). DOI: https://dx.doi.org/10.13140/RG.2.2.19798.60484

Setiawan, Adib Rifqi. (2019, March 23). Penggunaan Naḍom Mabādī 'Asyroh dalam Pembelajaran Biologi untuk Meningkatkan Motivasi dan Hasil Belajar. Seminar Nasional Biologi 2019 Inovasi Penelitian dan Pembelajaran Biologi III (IP2B III), Universitas Negeri Surabaya (UNESA). DOI: https://dx.doi.org/10.13140/RG.2.2.33220.37763

Setiawan, Adib Rifqi. (2018, November 24). Penerapan Pendekatan Saintifik untuk Melatih Literasi Saintifik dalam Domain Kompetensi pada Topik Gerak Lurus di Sekolah Menengah Pertama. Seminar Nasional Fisika ke-4 (SiNaFi IV), Universitas Pendidikan Indonesia (UPI). DOI: https://dx.doi.org/10.13140/RG.2.2.23154.04809

Setiawan, Adib Rifqi; Utari, Setiya; Nugraha, Muhamad Gina. (2016, December 17). Mengonstruksi Rancangan Soal Domain Kompetensi Literasi Saintifik Siswa SMP Kelas VIII pada Topik Gerak Lurus. Seminar Nasional Fisika ke-2 (SiNaFi II), Universitas Pendidikan Indonesia (UPI). DOI: https://dx.doi.org/10.13140/RG.2.2.31856.10246/1

Setiawan, Adib Rifqi. (2020, May 12). Introducing the Indonesian Education System. Thesis Commons. DOI: https://doi.org/10.31237/osf.io/ygt5c

Setiawan, A. R. (2020, May 7). Discovering the Fundamental Problem of Four Methods to Analyze Data. Thesis Commons. DOI: https://doi.org/10.31237/osf.io/h953y

Setiawan, Adib Rifqi. (2020, May 6). Menyibak Makna Karya Fadhilaturrahmi. LIS Scholarship Archive. DOI: https://doi.org/10.31229/osf.io/65y4z

Setiawan, Adib Rifqi. (2020, May 6). Discovering the Meaning of Fadhilaturrahmi's Work. Thesis Commons. DOI: https://doi.org/10.31237/osf.io/krf7z

Feldman, DarHalevy; \& Setiawan, Adib Rifqi. (2020, April 24). Education in Israel. Thesis Commons. DOI: https://doi.org/10.31237/osf.io/62shg

Setiawan, Adib Rifqi. (2020, April 18). Musyāfahah al-Qur'ān Melalui Media Elektronik. Thesis Commons. URL: https://thesiscommons.org/ntjp9/

Setiawan, Adib Rifqi. (2020, April 14). Jalāl al-Dīn 'Abd al-Roḥmān ibn Abī Bakr al-Suyūṭ̣̂. SocArXiv. DOI: https://doi.org/10.31235/osf.io/5zf9v

Setiawan, Adib Rifqi. (2020, April 14). Commodification of the Sexuality in Kim Kardashian's Instagram Posts. SocArXiv. DOI: https://doi.org/10.31235/osf.io/kd6au

Velasufah, Whasfi; \& Setiawan, Adib Rifqi. (2020, April 13). Nilai Pesantren Sebagai Dasar Pendidikan Karakter. Thesis Commons. DOI: https://doi.org/10.31237/osf.io/hq6kz

Setiawan, Adib Rifqi. (2020, April 13). Commodification of the Sexuality in Kim Kardashian's Instagram Posts. Thesis Commons. URL: https://thesiscommons.org/mf7nw/

Setiawan, Adib Rifqi. (2020, April 13). مبادئ اللغة العربية. Thesis Commons. DOI: https://doi.org/10.31237/osf.io/2gvjf

Siayah, Syarofis; \& Setiawan, Adib Rifqi. (2020, April 13). A Brief Explanation of Science Education. EdArXiv. DOI: https://doi.org/10.35542/osf.io/2evn3 
Siayah, Syarofis; \& Setiawan, Adib Rifqi. (2020, April 13). A Brief Explanation of Science Education.

Thesis Commons. DOI: https://doi.org/10.31237/osf.io/wkvsn

Setiawan, Adib Rifqi; \& Ilmiyah, Surotul. (2020, April 13). Multiple Intelligences Based on

Neuroscience. Thesis Commons. DOI: https://doi.org/10.31237/osf.io/e9fyu

Setiawan, Adib Rifqi; \& Ilmiyah, Surotul. (2020, April 13). Kecerdasan Majemuk Berdasarkan

Neurosains. EdArXiv. DOI: https://doi.org/10.35542/osf.io/rj2fe

Setiawan, Adib Rifqi. (2020, April 9). Islamic Education in Southeast Asia. EdArXiv. DOI: https://doi.org/10.35542/osf.io/dnjqv

Setiawan, Adib Rifqi. (2020, April 9). Islamic Education in Southeast Asia. Thesis Commons. DOI: https://doi.org/10.31237/osf.io/e794d

Ilmiyah, Surotul; \& Setiawan, Adib Rifqi. (2020, April 7). Students' Worksheet for Distance Learning Based on Scientific Literacy in the Topic Coronavirus Disease 2019 (COVID-19). Thesis Commons. DOI: https://doi.org/10.31237/osf.io/fpg4j

Ilmiyah, Surotul; \& Setiawan, Adib Rifqi. (2020, April 7). Students' Worksheet for Distance Learning Based on Scientific Literacy in the Topic Coronavirus Disease 2019 (COVID-19).

EdArXiv. DOI: https://doi.org/10.35542/osf.io/wyz5v

Setiawan, Adib Rifqi; \& Ilmiyah, Surotul. (2020, April 7). Lembar Kegiatan Siswa untuk Pembelajaran Jarak Jauh Berdasarkan Literasi Saintifik pada Topik Penyakit Coronavirus 2019 (COVID-19). EdArXiv. DOI: https://doi.org/10.35542/osf.io/h4632

Setiawan, Adib Rifqi. (2020, April 5). The Arrogant One. Thesis Commons. DOI: https://doi.org/10.31237/osf.io/8nmku

Setiawan, Adib Rifqi. (2020, April 4). Grace Natalie Louisa. SocArXiv. DOI: https://doi.org/10.31235/osf.io/zwf6g

Setiawan, Adib Rifqi. (2020, April 4). Grace Natalie Louisa. Thesis Commons. DOI: https://doi.org/10.31237/osf.io/u3mxv

Setiawan, Adib Rifqi. (2020, April 3). Sharifah Halimah Alaydrus : a female preachers for our time. SocArXiv. DOI: https://doi.org/10.31235/osf.io/zb8qe

Setiawan, Adib Rifqi. (2020, April 2). Desain Pembelajaran untuk Membimbing Siswa Sekolah Dasar dalam Memperoleh Literasi Saintifik. EdArXiv. DOI: https://doi.org/10.35542/osf.io/u59f8

Setiawan, Adib Rifqi. (2020, April 2). What is the Best Way to Analyze Pre-Post Data?. EdArXiv. DOI: https://doi.org/10.35542/osf.io/h4e6q

Setiawan, Adib Rifqi. (2020, April 2). JUPE My Uncut Story. Open Science Framework (OSF). DOI: https://doi.org/10.31219/osf.io/qdxga

Setiawan, Adib Rifqi. (2020, April 1). Syarifah Halimah Alaydrus. Thesis Commons. DOI: https://doi.org/10.31237/osf.io/xbmcs

Setiawan, Adib Rifqi. (2020, April 1). Sharifah Halimah Alaydrus. Thesis Commons. DOI: https://doi.org/10.31237/osf.io/fp79c

Setiawan, Adib Rifqi. (2019, October 8). Biografi Clara Ng Perempuan Penulis Asal Indonesia. PsyArXiv. DOI: https://doi.org/10.31234/osf.io/yk8sx

Setiawan, Adib Rifqi. (2019, December 23). Contoh Langkah Pembelajaran Berorientasi Literasi Saintifik. santrimilenial.net. URL: https://santrimilenial.net/contoh-langkahpembelajaran-berorientasi-literasi-saintifik/

Setiawan, Adib Rifqi. (2019, June 14). Deasy Noviyanti, Perempuan Berbadan Defisit Lemak. qureta.com. URL: https://www.qureta.com/next/post/deasy-noviyanti-perempuanberbadan-defisit-lemak

Setiawan, Adib Rifqi. (2018, December 18). Irma Rahma Suwarma. qureta.com. URL: https://www.qureta.com/next/post/irma-rahma-suwarma 
Setiawan, Adib Rifqi. (2018, October 05). Karen Armstrong. qureta.com. URL:

https://www.qureta.com/next/post/karen-armstrong

Setiawan, Adib Rifqi. (2018, September 17). Lola Zieta Azelien. qureta.com. URL: https://www.qureta.com/next/post/lola-zieta-azelien

Setiawan, Adib Rifqi. (2018, July 16). Rustriningsih, Srikandi Tersisih. qureta.com. URL: https://www.qureta.com/next/post/rustriningsih-srikandi-tersisih

Setiawan, Adib Rifqi. (2018, July 03). Tangis Daniela Hantuchová. qureta.com. URL: https://www.qureta.com/next/post/tangis-daniela-hantuchova

Setiawan, Adib Rifqi. (2018, June 28). Dewi Perssik. qureta.com. URL: https://www.qureta.com/next/post/dewi-perssik

Setiawan, Adib Rifqi. (2018, June 27). Ice. qureta.com. URL: https://www.qureta.com/next/post/ice

Setiawan, Adib Rifqi. (2018, May 24). Fakhrun. qureta.com. URL: https://www.qureta.com/next/post/fakhrun

Setiawan, Adib Rifqi. (2018, April 10). Eny Rochmawati Octaviani: memberikan hiburan, menyuntikkan harapan. Majalah SANTRI, 8: 15-18. URL: https://issuu.com/majalahsantri/docs/majalah_santri_8/17

Setiawan, Adib Rifqi. (2018, April 10). Busana: pemantas raga, pelaras jiwa. Majalah SANTRI, 8: 26-27. URL: https://issuu.com/majalahsantri/docs/majalah_santri_8/28

Setiawan, Adib Rifqi. (2018, April 10). Rosa Amalia Iqony: paduan yakin diri dan rendah hati. Majalah SANTRI, 8: 46. URL: https://issuu.com/majalahsantri/docs/majalah_santri_8/48

Setiawan, Adib Rifqi. (2018, March 25). Novi Kaka: Sahabat, Panutan, Pembimbing. qureta.com. URL: https://www.qureta.com/next/post/novi-kaka-sahabat-panutan-pembimbing

Setiawan, Adib Rifqi. (2018, March 21). Bidadari di Kesunyian itu Bernama Maria Sharapova. qureta.com. URL: https://www.qureta.com/next/post/bidadari-di-kesunyian-itubernama-maria-sharapova

Setiawan, Adib Rifqi. (2018, March 19). Airin Rachmi Diany, Lilin Penerang Masyarakat Urban. qureta.com. URL: https://www.qureta.com/next/post/airin-rachmi-diany-lilin-penerangmasyarakat-urban

Setiawan, Adib Rifqi. (2018, March 19). Kamu dalam Aku: A Brief Story of Park Bom. qureta.com. URL: https://www.qureta.com/next/post/kamu-dalam-aku-a-brief-story-of-park-bom

Setiawan, Adib Rifqi. (2018, March 19). Guru yang Menyapih: Catatan Perjalanan Pribadi Nong Darol Mahmada. qureta.com. URL: https://www.qureta.com/next/post/guru-yang-menyapihcatatan-perjalanan-pribadi-nong-darol-mahmada

Setiawan, Adib Rifqi. (2018, March 17). Maryam Musfiroh: An Educator for Our Time. qureta.com. URL: https://www.qureta.com/next/post/maryam-musfiroh-an-educator-for-our-time

Setiawan, Adib Rifqi. (2018, March 15). Eny R. Octaviani. qureta.com. URL: https://www.qureta.com/next/post/eny-r-octaviani

Setiawan, Adib Rifqi. (2018, March 14). Surely You're Joking, Mrs. Ilmy!. qureta.com. URL: https://www.qureta.com/next/post/surely-you-re-joking-mrs-ilmy

Setiawan, Adib Rifqi. (2018, March 14). Meniti Ilmuwati. qureta.com. URL: https://www.qureta.com/next/post/meniti-ilmuwati 
Setiawan, Adib Rifqi. (2018, March 12). Clara Ng. qureta.com. URL:

https://www.qureta.com/next/post/clara-ng

Setiawan, Adib Rifqi. (2018, March 11). Kisah Kasih Ayah di Balik Mata Najwa. qureta.com. URL: https://www.qureta.com/next/post/kisah-kasih-ayah-di-balik-mata-najwa

Setiawan, Adib Rifqi. (2018, March 11). Rosa Amalia Iqony. qureta.com. URL: https://www.qureta.com/next/post/rosa-amalia-iqony

Setiawan, Adib Rifqi. (2018, March 10). Venice Min. qureta.com. URL: https://www.qureta.com/next/post/venice-min

Setiawan, Adib Rifqi. (2018, March 09). Ketika YoonA Menyaksikan Real Madrid Menghempaskan PSG. qureta.com. URL: https://www.qureta.com/next/post/ketika-yoona-menyaksikan-realmadrid-menghempaskan-psg

Setiawan, Adib Rifqi. (2018, March 09). Kepedulian Airin Rachmi Diany pada Pendidikan. qureta.com. URL: https://www.qureta.com/next/post/kepedulian-airin-rachmi-diany-padapendidikan

Setiawan, Adib Rifqi. (2018, March 09). Laila Fariha Zein (a.k.a. Uus atau Febi). qureta.com. URL: https://www.qureta.com/next/post/laila-fariha-zein-febi

Setiawan, Adib Rifqi. (2018, March 09). Pantat Perekat Umat. qureta.com. URL: https://www.qureta.com/next/post/pantat-perekat-umat

Setiawan, Adib Rifqi. (2018, March 09). Sisi Religi Grace Natalie. qureta.com. URL: https://www.qureta.com/next/post/sisi-religi-grace-natalie

Setiawan, Adib Rifqi. (2018, March 09). Asal Usul Nama Via Vallen. qureta.com. URL: https://www.qureta.com/next/post/asal-usul-nama-via-vallen

Setiawan, Adib Rifqi. (2018, March 07). Mengenal Oza Kioza. qureta.com. URL: https://www.qureta.com/next/post/mengenal-oza-kioza

Setiawan, Adib Rifqi. (2018, March 06). Menyoal Vokal Duo Serigala. qureta.com. URL: https://www.qureta.com/next/post/menyoal-vokal-duo-serigala

Setiawan, Adib Rifqi. (2018, March 06). Breast Capital. qureta.com. URL: https://www.qureta.com/next/post/breast-capital

Amatullah; \& Setiawan, Adib Rifqi. (2017, October 10). Nadirsyah Hosen: berkarya sebagai diaspora. Majalah SANTRI, 7: 56-59 . URL: https://issuu.com/majalahsantri/docs/santri_edisi_7/58

Setiawan, Adib Rifqi. (2017, June 03). Dari Yuli Hingga Julia. qureta.com. URL: https://www.qureta.com/next/post/dari-yuli-hingga-julia-2

Setiawan, Adib Rifqi. (2017, June 02). Aisha. qureta.com. URL: https://www.qureta.com/next/post/aishahumaira

Setiawan, Adib Rifqi. (2015, November 10). Kehidupan Asmara Hawking: raga lumpuh, jiwa masih bisa tersentuh. fisikanet.lipi.go.id. URL: http://www.fisikanet.lipi.go.id/utama.cgi?artikel\&1447145876\&2

Setiawan, Adib Rifqi. (2015, November 07). Dibalik Sampul Buku A Brief History of Time, agar pengetahuan tak hanya dinikmati ilmuwan. fisikanet.lipi.go.id. URL: http://www.fisikanet.lipi.go.id/utama.cgi?artikel\&1446855103\&2

Setiawan, Adib Rifqi. (2015, November 03). Dibalik Nama Besar Albert Einstein: Dari Politik, Asmara, hingga Matematika. fisikanet.lipi.go.id. URL:

http://www.fisikanet.lipi.go.id/utama.cgi?artikel\&1446556354\&2 
Setiawan, Adib Rifqi. (2015, October 31). Kurir Mikroskopis Alam Semesta bukan debu biasa.

fisikanet.lipi.go.id. URL:

http://www.fisikanet.lipi.go.id/utama.cgi?artikel\&1446304060\&2

Setiawan, Adib Rifqi. (2015, October 10). 10 Kejutan Subatomik. fisikanet.lipi.go.id. URL:

http://www.fisikanet.lipi.go.id/utama.cgi?artikel\&1444577286\&3 